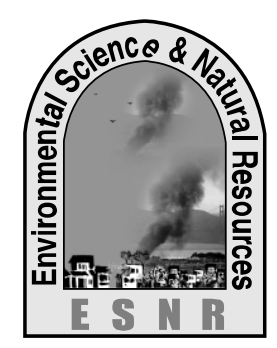

\title{
Yield and Nutrient Content of Tomato as Influenced by the Application of Vermicompost and Chemical Fertilizers
}

\author{
S. Mukta ${ }^{1}$, M. M. Rahman ${ }^{1}$ and M. G. Mortuza ${ }^{2}$ \\ ${ }^{1}$ Department of Agricultural Chemistry, Bangladesh Agricultural University \\ Mymensingh \\ ${ }^{2}$ Department of Biochemistry and Molecular Biology, Bangladesh Agricultural \\ University, Mymensingh \\ *Corresponding author:mmr@bau.edu.bd
}

\begin{abstract}
A pot experiment was conducted to investigate the yield and nutrient content of tomato (Lycopersicon esculentum) as influenced by the application of vermicompost and chemical fertilizers. The experiment was laid out in a completely randomized design (CRD) with 3 replications and comprised of 8 treatments viz., $\mathrm{T}_{1}$ - control, $\mathrm{T}_{2}$ - recommended dose of NPK fertilizers (CF), $\mathrm{T}_{3}-$ vermicompost @ 5 $\mathrm{t} \mathrm{ha}^{-1}\left(\mathrm{VC}_{1}\right), \mathrm{T}_{4}$ - vermicompost @ $10 \mathrm{tha}^{-1}\left(\mathrm{VC}_{2}\right), \mathrm{T}_{5}-\mathrm{VC}_{1}+50 \% \mathrm{CF}, \mathrm{T}_{6}-\mathrm{VC}_{1}+75 \% \mathrm{CF}, \mathrm{T}_{7}-\mathrm{VC}_{2}+50 \% \mathrm{CF}$ and $\mathrm{T}_{8}-\mathrm{VC}_{2}+75 \%$ $\mathrm{CF}$. Application of vermicompost @ $10 \mathrm{t} \mathrm{ha}^{-1}$ along with 50\% chemical fertilizers showed the best performance for plant height, number of leaves plant ${ }^{-1}$, number of flowers branch ${ }^{-1}$, number of fruits branch ${ }^{-1}$, number of fruits plant ${ }^{-1}$, fruit size and yield of tomato. Vermicompost treated soils significantly contributed the highest contents of sugar, $\mathrm{pH}, \mathrm{N}, \mathrm{P}, \mathrm{K}, \mathrm{Ca}, \mathrm{Mg}, \mathrm{S}, \mathrm{Zn} \& \mathrm{~B}$ in tomato, influenced nutrient status of the postharvest soil and conserved more organic $\mathrm{C}, \mathrm{N}, \mathrm{P}, \mathrm{K}, \mathrm{Ca}, \mathrm{Mg}, \mathrm{S}, \mathrm{Zn} \& \mathrm{~B}$ contents over control. However, soluble solids and vitamin $\mathrm{C}$ content in tomato were not significantly influenced by the application of vermicompost and chemical fertilizers. Results of the study demonstrate that the combined application of vermicompost and chemical fertilizers would help to maintain the long-term soil productivity for sustainable tomato cultivation.
\end{abstract}

Key words: Chemical fertilizer, Nutrient content, Tomato, Vermicompost, Yield

\section{Introduction}

Organic farming is a production system, which avoids or largely excludes the use of synthetic chemical fertilizers. The continued use of organic fertilizers increases soil organic matter, better water infiltration and aeration, higher soil biological activity as the materials decompose in soil and increases yields after the year of application (Ceglarek et al., 2002). The effectiveness of such materials can be improved by combining them with chemical fertilizers. Vermicompost can play a vital role in sustaining soil fertility and crop production more than the use of chemical fertilizers. Vermicompost is an excellent product because it tends to hold more nutrients over a longer period without adversely affecting the environment. Among the sources of available organic manures, vermicompost contains a higher percentage of nutrients necessary for plant growth in readily available forms (Theunissen et al., 2010; Bhat and Limaye, 2012). It increases macropore space resulting in improved air-water relationship in the soil, which favorably affects plant growth (Marinari et al., 2000). The application of organic fertilizers including vermicompost favorably affects soil $\mathrm{pH}$, microbial population and soil enzyme activities (Maheswarappa et al., 1999). The indiscriminate use of chemical fertilizers drastically destroys the physical, chemical and biological properties of soil. Besides, owing to the repeated use of land and chemical fertilizers, our land has become unfertile and lost its productivity. Vermicompost treatment plots displayed better results with regard to growth and fruit yield of tomato plant as compared to control (Arancon et al., 2003; Chanda et al., 2011; Abduli et al., 2013). Chemical fertilizers may be used more efficiently by crops growing on soils with adequate amounts of soil organic matter supplied by organic fertilizers (Chadha et al., 2006). Integrated use of vermicompost as organic fertilizer and chemical fertilizers would be quite promising in soil fertility improvement. The present-day-concern about global environmental pollution can be reduced to a considerable extent by either judicious use of chemical fertilizers or increase the use of manures. The use of manures and their proper management may reduce the need for chemical fertilizers, thus allowing the small farmers to save in part the cost of production. In Bangladesh, there is a great possibility of increasing tomato yield per unit area with the judicious use of organic fertilizers. For this reason, the effect of vermicompost along with chemical fertilizers on tomato (Lycopersicon esculentum) as one of the important vegetable crops is considered in this study.

\section{Materials and Methods}

\section{Experimental set up}

Vermicompost was collected from Department of Agricultural Chemistry, Bangladesh Agricultural University, Mymensingh. In this experiment, tomato cv. BARI Tomato-14 was used as a test crop. Seeds were collected from Horticulture Division, Bangladesh Agricultural Research Institute, Joydebpur, Gazipur. The experiment was laid out in a completely randomized design (CRD) with 3 replications. The pot experiment comprised of 8 treatments viz., $\mathrm{T}_{1}$ - control (no compost and chemical fertilizers), $\mathrm{T}_{2}$ - recommended dose of NPK fertilizers $(\mathrm{CF}), \mathrm{T}_{3}$ - vermicompost @ $5 \mathrm{t} \mathrm{ha}^{-1}\left(\mathrm{VC}_{1}\right), \mathrm{T}_{4}$ vermicompost@10 t ha ${ }^{-1}\left(\mathrm{VC}_{2}\right), \mathrm{T}_{5}$ - vermicompost @ 5 $\mathrm{t} \mathrm{ha}^{-1}$ and $50 \% \mathrm{CF}\left(\mathrm{VC}_{1}+50 \% \mathrm{CF}\right), \mathrm{T}_{6}$ - vermicompost @ $5 \mathrm{t} \mathrm{ha}^{-1}$ and $75 \% \mathrm{CF}\left(\mathrm{VC}_{1}+75 \% \mathrm{CF}\right), \mathrm{T}_{7}$ - vermicompost @ $10 \mathrm{t} \mathrm{ha}^{-1}$ and $50 \% \mathrm{CF}\left(\mathrm{VC}_{2}+50 \% \mathrm{CF}\right)$ and $\mathrm{T}_{8}-$ vermicompost @ $10 \mathrm{t} \mathrm{ha}^{-1}$ and $75 \% \mathrm{CF}\left(\mathrm{VC}_{2}+75 \% \mathrm{CF}\right)$. After collection, soil samples were pulverized, air dried and then mixed thoroughly. Soil samples were placed in 
each pot at the rate of $10 \mathrm{~kg} \mathrm{pot}^{-1}$. Vermicompost and recommended doses of NPK fertilizers were mixed thoroughly with soil as per the experimental treatment. All treatments of this experiment were assigned at random to each unit pot for each replication. Different parameters such as plant height, number of leaves plant ${ }^{-1}$, number of flowers branch ${ }^{-1}$, number of fruits branch ${ }^{-1}$, number of fruits plant ${ }^{-1}$, fruit size and yield were recorded from all tomato plants. Plant samples were collected from each pot, dried in an oven at $60^{\circ} \mathrm{C}$ for about $72 \mathrm{~h}$ and ground to pass through a 20-mesh sieve.

\section{Soil and plant analysis}

The biochemical constituents like $\mathrm{pH}$, vitamin $\mathrm{C}$, reducing sugar and total soluble solids were measured from tomato fruits. The $\mathrm{pH}$ value of filtrable syrups prepared from fruit samples was measured by $\mathrm{pH}$ meter (Model: Jenway-3505); vitamin C was determined by indophenols dye extraction method and sugar content was estimated by determining the volume of unknown sugar solution of tomato pulp required for complete reduction of standard Fehling's solution (Ranganna, 1994). Soil texture of initial and postharvest soils was determined by hydrometer method (Black, 1965). The $\mathrm{pH}$ of initial and post harvest soils was determined by $\mathrm{pH}$ meter (Model: Jenway 3505) as stated by Jackson (1973). Organic C content of soil samples was estimated by wet oxidation method (Ghosh et al., 1983). The determination of total$\mathrm{N}$ in plant samples was performed by semi-micro kjeldahl method (Page et al., 1982; Tandon, 1995). Plant and fruit samples were digested by wet oxidation method using diacid mixture $\left(\mathrm{HNO}_{3}: \mathrm{HClO}_{4}=2: 1\right)$ for the determination of $\mathrm{P}, \mathrm{K}, \mathrm{Ca}, \mathrm{Mg}, \mathrm{S}, \mathrm{Zn}$ and B contents as described by Singh et al. (1999). Available $\mathrm{P}$ in soil was extracted with $\mathrm{NaHCO}_{3}(0.5 \mathrm{M})$ at $\mathrm{pH} 8.5$ and its content in both soil and plant extracts was determined by spectrophotometric method using stannous chloride $\left(\mathrm{SnCl}_{2} \cdot 2 \mathrm{H}_{2} \mathrm{O}\right)$ as reducing agent (Jackson, 1973; Tandon, 1995). Exchangeable K, $\mathrm{Ca}$ and $\mathrm{Mg}$ were obtained from soil samples by extracting with $1 \mathrm{~N} \mathrm{NH} \mathrm{NH}_{4} \mathrm{OAc}$ at $\mathrm{pH} 7$ and $\mathrm{K}$ content in both extracts was determined by flame photometric method (Tandon, 1995). The contents of $\mathrm{Ca}$ and $\mathrm{Mg}$ were estimated from both extracts by EDTA titrimetric method using $\mathrm{Na}_{2}$ EDTA as a complexing agent (Page et al., 1982). Available $\mathrm{S}$ was extracted from soil samples using $\mathrm{CaCl}_{2}$ solution and $\mathrm{S}$ content in both soil and plant extracts was determined turbidimetrically with the help of spectrophotometer (Model: Labtronics LT-31) as described by Page et al. (1982) and Tandon (1995). Available B was extracted with hot water from soil samples and its content in both extracts was determined by spectrophotometer (Model: Labtronics LT-31) using azomethine-H (Page et al., 1982; Tandon, 1995). Available $\mathrm{Zn}$ was extracted with $\mathrm{Na}_{2}$ EDTA from soil samples (McLaren et al., 1984) and $\mathrm{Zn}$ content was directly analyzed by atomic absorption spectrophotometer (Model: Varian-55B) as mentioned by Singh et al. (1999).

\section{Statistical analysis}

The recorded data were subjected to statistical analysis following Completely Randomized Design (CRD) with the help of computer package program. The significance of difference between treatment means was evaluated by Duncan's Multiple Range Test (DMRT) and the mean comparisons of treatments were adjusted by Least Significant Difference (LSD) test at $1 \%$ level of probability (Gomez and Gomez, 1984).

\section{Results and Discussion}

\section{Effect of vermicompost and chemical fertilizers on} plant characters and yield of tomato

Effect of vermicompost along with chemical fertilizers on plant characters and yield of tomato were statistically significant (Table 1). Plant height varied from 98.33 to $185.00 \mathrm{~cm}$ at the harvesting stage. The highest plant height was found from vermicompost at the rate of $10 \mathrm{t} \mathrm{ha}^{-1}$ and $50 \%$ chemical fertilizers treated plants $\left(\mathrm{T}_{7}\right.$ treatment) and the lowest plant height was observed in control plant $\left(\mathrm{T}_{1}\right.$ treatment). The highest number of leaves plant $^{-1}$ (105) was found from vermicompost at the rate of $10 \mathrm{tha}^{-1}$ and $50 \%$ chemical fertilizers treated plants $\left(\mathrm{T}_{7}\right.$ treatment) and the lowest number of leaves plant ${ }^{-1}$ (55) was obtained in control plant $\left(\mathrm{T}_{1}\right.$ treatment). That result was identical to $\mathrm{T}_{8}$ treatment where vermicompost at the rate of $10 \mathrm{t}$ ha ${ }^{1}$ and $75 \%$ chemical fertilizers were applied. Maximum number of leaves plant ${ }^{-1}$ (105.00) was obtained from vermicompost treated soil along with $50 \%$ chemical fertilizers ( $\mathrm{T}_{7}$ treatment) as compared to control soil. A possible response behind this finding was possibly due to the addition of organic manure (Jin et al., 1996). The highest number of flowers branch ${ }^{-1}$ (12) was obtained from vermicompost at the rate of $10 \mathrm{t} \mathrm{ha}^{-1}$ and $50 \%$ chemical fertilizers treated plants $\left(\mathrm{T}_{7}\right.$ treatment $)$ and the lowest number of flowers plant ${ }^{-1}$ (7.67) was obtained in control plant $\left(\mathrm{T}_{1}\right.$ treatment). The application of vermicompost up to $2 \mathrm{t} \mathrm{ha}^{-1}$ increased secondary branches plant ${ }^{-1}$ (Naresh, 2002). It is evident from the results that the number of flowers branch ${ }^{-1}$ was influenced by the application of vermicompost along with chemical fertilizers. The number of fruits branch $^{-1}$ varied significantly among different treatments. The highest number of fruits branch ${ }^{-1}(10.00)$ was obtained from vermicompost @ at the rate of 10 tha $^{-1}$ and 50\% chemical fertilizers treated plants $\left(\mathrm{T}_{7}\right.$ treatment) and the lowest number of fruits branch ${ }^{-1}(5.00)$ was obtained in control plant. The highest number of fruits plant ${ }^{-1}(20)$ was obtained from vermicompost at the rate of $10 \mathrm{t} \mathrm{ha}^{-1}$ and $50 \%$ chemical fertilizers treated plants $\left(\mathrm{T}_{7}\right.$ treatment) and the lowest number of fruits plant ${ }^{-1}(5)$ was obtained in control plant. Maximum number of fruits plant ${ }^{-1}$ was obtained from vermicompost treated soil along with chemical fertilizers as compared to control soil. The highest length of fruits $(43.50 \mathrm{~mm})$ was obtained from vermicompost at the rate of $10 \mathrm{t} \mathrm{ha}^{-1}$ and $50 \%$ chemical fertilizers treated plants $\left(\mathrm{T}_{7}\right.$ treatment) and the lowest length of fruits $(21.00 \mathrm{~mm})$ was obtained in control plant. Plant grown with vermicompost at the rate of $10 \mathrm{t} \mathrm{ha}^{-1}$ along with 
chemical fertilizers gave the longest fruit length as compared to $\mathrm{T}_{1}$ (control) treatment. The highest breadth of fruits $(46.67 \mathrm{~mm})$ was obtained from vermicompost at the rate of $10 \mathrm{t} \mathrm{ha}^{-1}$ and $50 \%$ chemical fertilizers treated plants $\left(\mathrm{T}_{7}\right.$ treatment) and the lowest breadth of fruits $(31.93 \mathrm{~mm})$ was obtained in control plant. Plant grown with vermicompost at the rate of $10 \mathrm{tha}^{-1}$ along with chemical fertilizers gave the longest fruit breadth where as the shortest fruit breadth was obtained from $T_{1}$ (control) treatment. Vermicompost had significant effect on fruit size of tomato. The highest fruit yield $\left(75.00 \mathrm{t} \mathrm{ha}^{-1}\right.$ ) was recorded in $\mathrm{T}_{7}$ treatment where vermicompost at the rate of $10 \mathrm{t} \mathrm{ha}^{-1}$ along with $50 \%$ chemical fertilizers were applied. In control plant, the lowest fruit yield $\left(24.67 \mathrm{t} \mathrm{ha}^{-1}\right)$ of tomato was obtained (Table 1). The findings indicated that the application of vermicompost had the best effect on fruit yield of tomato. Vermicompost with low level of chemical fertilizer also gave better results compared to higher level of chemical fertilizer. Similar trend of result was reported by Yadav et al. (2001). The highest application of vermicompost showed the best performance on plant characters and fruit yield of tomato. All other treatments also showed better results over control but did not exhibit better results as compared to $\mathrm{T}_{7}$ (vermicompost @ $10 \mathrm{t} \mathrm{ha}^{-1}$ and $50 \%$ chemical fertilizers) and $\mathrm{T}_{8}$ (vermicompost @ $10 \mathrm{t} \mathrm{ha}^{-1}$ and $75 \%$ chemical fertilizers) treatments.

Table 1. Effect of vermicompost and chemical fertilizers on plant characters and yield of tomato

\begin{tabular}{|c|c|c|c|c|c|c|c|c|}
\hline Treatments & $\begin{array}{l}\text { Plant height } \\
(\mathrm{cm})\end{array}$ & $\begin{array}{l}\text { No. of } \\
\text { leaves } \\
\text { plant }^{-1}\end{array}$ & $\begin{array}{l}\text { No. of } \\
\text { flowers } \\
\text { branch }^{-1}\end{array}$ & $\begin{array}{l}\text { No. of } \\
\text { fruits } \\
\text { branch }^{-1}\end{array}$ & $\begin{array}{l}\text { No. of } \\
\text { fruits } \\
\text { plant }^{-1}\end{array}$ & $\begin{array}{l}\text { Fruit length } \\
\quad(\mathrm{mm})\end{array}$ & $\begin{array}{l}\text { Fruit breadth } \\
(\mathrm{mm})\end{array}$ & $\begin{array}{c}\text { Fruit yield } \\
\left(\mathrm{t} \mathrm{ha}^{-1}\right)\end{array}$ \\
\hline $\mathrm{T}_{1}$ - Control & $98.33 \mathrm{e}$ & $55.00 \mathrm{e}$ & $7.67 \mathrm{e}$ & $5.00 \mathrm{e}$ & $5.00 \mathrm{e}$ & $21.00 \mathrm{e}$ & $31.93 \mathrm{e}$ & $24.67 \mathrm{e}$ \\
\hline $\mathrm{T}_{2}-\mathrm{CF}$ & $100.00 \mathrm{~d}$ & $65.78 \mathrm{~d}$ & $7.87 \mathrm{~d}$ & $6.52 \mathrm{~d}$ & $6.33 d$ & $27.00 \mathrm{~d}$ & $32.33 d$ & $27.33 d$ \\
\hline $\mathrm{T}_{3}-\mathrm{VC}_{1}$ & $136.00 \mathrm{c}$ & $71.33 c$ & $8.33 c$ & $7.59 \mathrm{c}$ & $8.12 \mathrm{c}$ & $35.12 \mathrm{c}$ & $36.00 \mathrm{c}$ & $40.87 \mathrm{c}$ \\
\hline $\mathrm{T}_{4}-\mathrm{VC}_{2}$ & $139.00 \mathrm{c}$ & $72.33 c$ & $8.67 \mathrm{c}$ & $7.68 \mathrm{c}$ & $8.67 \mathrm{c}$ & $37.33 c$ & $37.33 c$ & $42.00 \mathrm{c}$ \\
\hline $\mathrm{T}_{5}-\mathrm{VC}_{1}+50 \% \mathrm{CF}$ & $181.20 \mathrm{~b}$ & $86.33 b$ & $9.87 \mathrm{~b}$ & $9.22 b$ & $15.33 b$ & $40.67 b$ & $42.33 b$ & $65.30 \mathrm{~b}$ \\
\hline $\mathrm{T}_{6}-\mathrm{VC}_{1}+75 \% \mathrm{CF}$ & $181.00 \mathrm{~b}$ & $85.82 b$ & $9.67 b$ & $9.31 \mathrm{~b}$ & $14.87 \mathrm{~b}$ & $40.33 b$ & $42.00 \mathrm{~b}$ & $62.87 \mathrm{~b}$ \\
\hline $\mathrm{T}_{7}-\mathrm{VC}_{2}+50 \% \mathrm{CF}$ & $185.00 \mathrm{a}$ & $105.00 \mathrm{a}$ & $12.00 \mathrm{a}$ & $10.00 \mathrm{a}$ & $20.00 \mathrm{a}$ & $43.50 \mathrm{a}$ & $46.67 a$ & $75.00 \mathrm{a}$ \\
\hline $\mathrm{T}_{8}-\mathrm{VC}_{2}+75 \% \mathrm{CF}$ & $182.30 \mathrm{a}$ & $99.00 \mathrm{a}$ & $10.33 a$ & $9.87 \mathrm{a}$ & $18.67 \mathrm{a}$ & $43.33 \mathrm{a}$ & $45.00 \mathrm{a}$ & $72.89 \mathrm{a}$ \\
\hline $\mathrm{LSD}_{0.05}$ & 11.46 & 4.08 & 0.54 & 0.23 & 0.57 & 3.00 & 2.76 & 2.82 \\
\hline Significance level & $* *$ & $* *$ & $* *$ & $* *$ & $* *$ & $* *$ & $* *$ & $* *$ \\
\hline $\mathrm{CV}(\%)$ & 4.76 & 3.17 & 3.55 & 5.97 & 3.10 & 4.87 & 4.22 & 3.71 \\
\hline
\end{tabular}

*** Significant at $1 \%$ level; $\mathrm{VC}_{1}=$ Vermicompost @ $5 \mathrm{t} \mathrm{ha}^{-1} ; \mathrm{VC}_{2}=$ Vermicompost @ $10 \mathrm{t} \mathrm{ha}^{-1}$ and $\mathrm{CF}=\mathrm{Recommended} \mathrm{dose}$ of chemical fertilizers. In a column, figures with same letter or without letter did not differ significantly whereas figures with dissimilar letter differed significantly as per DMRT.

\section{Effect of vermicompost and chemical fertilizers on biochemical constituent of tomato fruit}

The effect of different treatments on $\mathrm{pH}$ level of tomato fruits was statistically significant at $1 \%$ level of probability (Table 2). The highest $\mathrm{pH}$ of fruit (4.48) was recorded in vermicompost at the rate of $10 \mathrm{tha}^{-1}$ and $50 \%$ chemical fertilizers treated plants $\left(\mathrm{T}_{7}\right.$ treatment), which was statistically identical with other treatments and the lowest $\mathrm{pH}$ of fruit (3.50) was observed at $\mathrm{T}_{1}$ (control) treatment. Application of vermicompost alone also lowered the $\mathrm{pH}$ level of tomato fruit as compared to control treatment. Naresh (2002) opined that acidity of tomato fruits showed a marked increase with increasing level of chemical fertilizer, which was in agreement with the present findings. The highest total soluble solids content $(3.17 \%)$ was obtained in $\mathrm{T}_{7}$ (vermicompost @ $10 \mathrm{t} \mathrm{ha}^{-1}$ and $50 \%$ chemical fertilizers) treatment and the content of total soluble solids in fruit was minimum $(2.70 \%)$ in $\mathrm{T}_{6}$ treatment where vermicompost at the rate of $5 \mathrm{t} \mathrm{ha}^{-1}$ along with
$75 \%$ chemical fertilizers were applied (Table 2). The results represented that the highest vitamin $\mathrm{C}$ content (15.87 mg $100 \mathrm{~g}^{-1}$ ) was recorded in $\mathrm{T}_{5}$ (vermicompost @ $5 \mathrm{t} \mathrm{ha}^{-1}$ and $50 \%$ chemical fertilizers) treatment. On the other hand, the lowest vitamin $\mathrm{C}$ content $(12.33 \mathrm{mg}$ $\left.100 \mathrm{~g}^{-1}\right)$ was obtained in $\mathrm{T}_{7}$ ((vermicompost @ $10 \mathrm{t} \mathrm{ha}^{-1}$ and $50 \%$ chemical fertilizers $)$ ) treatment. However, it is evident from Table 2 that application of vermicompost under study individually or in combination had no any influence on vitamin $\mathrm{C}$ content of tomato fruits. The reducing sugar content of tomato fruits ranged from 2.12 to $2.89 \%$. The highest sugar content $(2.89 \%)$ was obtained in $\mathrm{T}_{7}$ (vermicompost @ $10 \mathrm{t} \mathrm{ha}^{-1}$ and $50 \%$ chemical fertilizers) treatment and the lowest content $(2.12 \%)$ was observed in $\mathrm{T}_{1}$ (control) treatment (Table 2). Vermicompost and chemical fertilizers influenced the content of reducing sugar in tomato fruit (Naresh, 2002). Abduli et al. (2013) reported that sugar content in tomato increased with using vermicompost. 
Table 2. Effect of vermicompost and chemical fertilizers on biochemical constituent of tomato fruit

\begin{tabular}{|c|c|c|c|c|}
\hline Treatments & $\mathrm{pH}$ & $\begin{array}{l}\text { Total soluble solids } \\
(\%)\end{array}$ & $\begin{array}{l}\text { Vitamin } \mathrm{C} \\
\left(\mathrm{mg} 100 \mathrm{~g}^{-1}\right)\end{array}$ & $\begin{array}{c}\text { Reducing sugar } \\
(\%)\end{array}$ \\
\hline $\mathrm{T}_{1}$ - Control & $3.50 \mathrm{c}$ & 3.02 & 12.67 & $2.12 \mathrm{~d}$ \\
\hline $\mathrm{T}_{2}-\mathrm{CF}$ & $4.45 \mathrm{a}$ & 2.80 & 12.67 & $2.26 \mathrm{a}$ \\
\hline $\mathrm{T}_{3}-\mathrm{VC}_{1}$ & $3.75 \mathrm{~d}$ & 3.00 & 13.00 & $2.29 \mathrm{c}$ \\
\hline $\mathrm{T}_{4}-\mathrm{VC}_{2}$ & $3.78 \mathrm{c}$ & 2.96 & 15.00 & $2.28 \mathrm{c}$ \\
\hline $\mathrm{T}_{5}-\mathrm{VC}_{1}+50 \% \mathrm{CF}$ & $4.29 \mathrm{~b}$ & 2.97 & 15.87 & $2.80 \mathrm{~b}$ \\
\hline $\mathrm{T}_{6}-\mathrm{VC}_{1}+75 \% \mathrm{CF}$ & $4.14 b$ & 2.70 & 14.70 & $2.39 \mathrm{~b}$ \\
\hline $\mathrm{T}_{7}-\mathrm{VC}_{2}+50 \% \mathrm{CF}$ & $4.48 \mathrm{a}$ & 3.17 & 12.33 & $2.89 \mathrm{a}$ \\
\hline $\mathrm{T}_{8}-\mathrm{VC}_{2}+75 \% \mathrm{CF}$ & $4.47 \mathrm{a}$ & 3.00 & 12.40 & $2.87 \mathrm{a}$ \\
\hline $\mathrm{LSD}_{0.05}$ & 0.14 & 0.13 & 0.99 & 0.22 \\
\hline Significance level & $* *$ & NS & NS & $* *$ \\
\hline $\mathrm{CV}(\%)$ & 2.09 & 1.09 & 3.04 & 5.56 \\
\hline
\end{tabular}

${ }^{* *}$ Significant at $1 \%$ level; ${ }^{\mathrm{NS}}$ Non-significant; $\mathrm{VC}_{1}=$ Vermicompost @ $5 \mathrm{t} \mathrm{ha}^{-1} ; \mathrm{VC}_{2}=$ Vermicompost @ $10 \mathrm{t} \mathrm{ha}^{-1}$ and $\mathrm{CF}=$ Recommended dose of chemical fertilizers. In a column, figures with same letter or without letter did not differ significantly whereas figures with dissimilar letter differed significantly as per DMRT.

\section{Effect of vermicompost and chemical fertilizers on nutrient content of tomato}

Vermicompost and chemical fertilizers significantly influenced $\mathrm{N}, \mathrm{P}, \mathrm{K}, \mathrm{Ca}, \mathrm{Mg}, \mathrm{B}$ and $\mathrm{Zn}$ contents of tomato (Tables $3 \& 4$ ). In this study, the highest nutrient contents of both fruit and plant was recorded from $\mathrm{T}_{7}$ (vermicompost @ $10 \mathrm{t} \mathrm{ha}^{-1}$ and $50 \%$ chemical fertilizers) treatment followed by $\mathrm{T}_{8}$ (vermicompost @ $10 \mathrm{t} \mathrm{ha}^{-1}$ and $75 \%$ chemical fertilizers) treatment.
Nitrogen content in tomato fruits was significantly affected by the use of vermicompost and chemical fertilizers. The content of $\mathrm{N}$ in fruits was from 0.27 to $0.59 \%$. The highest $\mathrm{N}$ content $(0.59 \%)$ in fruits was obtained in $\mathrm{T}_{7}$ (vermicompost @ $10 \mathrm{t} \mathrm{ha}^{-1}$ and $50 \%$ chemical fertilizers) treatment and the lowest $\mathrm{N}$ content $(0.27 \%)$ was recorded in $\mathrm{T}_{1}$ (control) treatment, which was significantly inferior to all treatments.

Table 3. Effect of vermicompost and chemical fertilizers on nutrient content of tomato fruit

\begin{tabular}{|l|c|c|c|c|c|c|c|c|}
\hline \multicolumn{1}{|c|}{ Treatments } & $\begin{array}{c}\mathrm{N} \\
(\%)\end{array}$ & $\begin{array}{c}\mathrm{P} \\
(\%)\end{array}$ & $\begin{array}{c}\mathrm{K} \\
(\%)\end{array}$ & $\begin{array}{c}\mathrm{Ca} \\
(\%)\end{array}$ & $\begin{array}{c}\mathrm{Mg} \\
(\%)\end{array}$ & $\begin{array}{c}\mathrm{S} \\
(\%)\end{array}$ & $\begin{array}{c}\mathrm{B} \\
\left(\mu \mathrm{g} \mathrm{g}^{-1}\right)\end{array}$ & $\begin{array}{c}\mathrm{Zn} \\
\left(\mu \mathrm{g} \mathrm{g}^{-1}\right)\end{array}$ \\
\hline $\mathrm{T}_{1}-\mathrm{Control}$ & $0.27 \mathrm{e}$ & $0.28 \mathrm{e}$ & $0.76 \mathrm{e}$ & $0.26 \mathrm{e}$ & $0.34 \mathrm{e}$ & $0.05 \mathrm{e}$ & $20.00 \mathrm{e}$ & $21.00 \mathrm{e}$ \\
\hline $\mathrm{T}_{2}-\mathrm{CF}$ & $0.31 \mathrm{~d}$ & $0.31 \mathrm{~d}$ & $0.79 \mathrm{~d}$ & $0.30 \mathrm{~d}$ & $0.36 \mathrm{~d}$ & $0.08 \mathrm{~d}$ & $21.00 \mathrm{~d}$ & $21.90 \mathrm{~d}$ \\
\hline $\mathrm{T}_{3}-\mathrm{VC}_{1}$ & $0.35 \mathrm{c}$ & $0.35 \mathrm{c}$ & $0.82 \mathrm{c}$ & $0.34 \mathrm{c}$ & $0.44 \mathrm{c}$ & $0.11 \mathrm{c}$ & $24.00 \mathrm{c}$ & $23.50 \mathrm{c}$ \\
\hline $\mathrm{T}_{4}-\mathrm{VC}_{2}$ & $0.37 \mathrm{c}$ & $0.36 \mathrm{c}$ & $0.84 \mathrm{c}$ & $0.37 \mathrm{c}$ & $0.44 \mathrm{c}$ & $0.12 \mathrm{c}$ & $25.00 \mathrm{c}$ & $23.97 \mathrm{c}$ \\
\hline $\mathrm{T}_{5}-\mathrm{VC}_{1}+50 \% \mathrm{CF}$ & $0.53 \mathrm{~b}$ & $0.43 \mathrm{~b}$ & $0.87 \mathrm{~b}$ & $0.42 \mathrm{~b}$ & $0.48 \mathrm{~b}$ & $0.24 \mathrm{~b}$ & $28.00 \mathrm{~b}$ & $28.70 \mathrm{~b}$ \\
\hline $\mathrm{T}_{6}-\mathrm{VC}_{1}+75 \% \mathrm{CF}$ & $0.51 \mathrm{~b}$ & $0.42 \mathrm{~b}$ & $0.87 \mathrm{~b}$ & $0.41 \mathrm{~b}$ & $0.48 \mathrm{~b}$ & $0.22 \mathrm{~b}$ & $27.00 \mathrm{~b}$ & $27.00 \mathrm{~b}$ \\
\hline $\mathrm{T}_{7}-\mathrm{VC}_{2}+50 \% \mathrm{CF}$ & $0.59 \mathrm{a}$ & $0.49 \mathrm{a}$ & $0.90 \mathrm{a}$ & $0.45 \mathrm{a}$ & $0.58 \mathrm{a}$ & $0.39 \mathrm{a}$ & $31.00 \mathrm{a}$ & $32.00 \mathrm{a}$ \\
\hline $\mathrm{T}_{8}-\mathrm{VC}_{2}+75 \% \mathrm{CF}$ & $0.56 \mathrm{a}$ & $0.47 \mathrm{a}$ & $0.88 \mathrm{a}$ & $0.43 \mathrm{a}$ & $0.49 \mathrm{a}$ & $0.25 \mathrm{~b}$ & $29.00 \mathrm{a}$ & $29.50 \mathrm{a}$ \\
\hline $\mathrm{LSD}_{0.05}$ & 0.052 & 0.091 & 0.052 & 0.075 & 0.074 & 0.053 & 1.02 & 2.04 \\
\hline Significance level & $* *$ & $* *$ & $* *$ & $* *$ & $* *$ & $* *$ & $* *$ & $* *$ \\
\hline $\mathrm{CV}(\%)$ & 7.36 & 14.20 & 4.38 & 11.95 & 10.40 & 17.67 & 5.44 & 4.83 \\
\hline
\end{tabular}

${ }^{* * *}$ Significant at $1 \%$ level; $\mathrm{VC}_{1}=$ Vermicompost @ $5 \mathrm{t} \mathrm{ha}^{-1} ; \mathrm{VC}_{2}=$ Vermicompost @ $10 \mathrm{t} \mathrm{ha}^{-1}$ and $\mathrm{CF}=\mathrm{Recommended} \mathrm{dose}$ of chemical fertilizers. In a column, figures with same letter or without letter did not differ significantly whereas figures with dissimilar letter differed significantly as per DMRT.

The content of $\mathrm{P}$ in tomato fruits varied from 0.28 to $0.49 \%$ (Table 3 ). The highest $\mathrm{P}$ content $(0.49 \%)$ was observed in $\mathrm{T}_{7}$ (vermicompost @ $10 \mathrm{t} \mathrm{ha}^{-1}$ and $50 \%$ chemical fertilizers) treatment and the lowest $\mathrm{P}$ content $(0.28 \%)$ in fruits was found in $\mathrm{T}_{1}$ (control) treatment. Potassium content in tomato fruits varied from 0.76 to $0.90 \%$. Maximum $\mathrm{K}$ content $(0.90 \%)$ of fruit was obtained in $\mathrm{T}_{7}$ (vermicompost @ $10 \mathrm{t} \mathrm{ha}^{-1}$ and $50 \%$ chemical fertilizers) treatment and minimum $\mathrm{K}$ content $(0.76 \%)$ was observed in $\mathrm{T}_{1}$ (control) treatment. The result showed that $\mathrm{K}$ content was increased with the application of vermicompost and chemical fertilizers. Singh (2001) opined that K content in tomato fruits increased due to the combination of vermicompost and chemical fertilizers. The content of $\mathrm{Ca}$ in tomato fruits varied from 0.26 to $0.45 \%$ and that was minimum $(0.26 \%)$ in $\mathrm{T}_{1}$ (control) treatment. Maximum Ca content $(0.45 \%)$ in fruits was observed in $\mathrm{T}_{7}$ treatment where vermicompost at the rate of $10 \mathrm{t} \mathrm{ha}^{-1}$ along with $50 \%$ chemical fertilizers were applied. Maximum content of 
$\mathrm{Mg}(0.58 \%)$ in tomato fruits was observed in $\mathrm{T}_{7}$ (vermicompost @ $10 \mathrm{t} \mathrm{ha}^{-1}$ and $50 \%$ chemical fertilizers) treatment and it was minimum $(0.34 \%)$ in $\mathrm{T}_{1}$ (control) treatment. The content of $\mathrm{Mg}$ in tomato was significantly influenced by the effect of vermicompost with different levels of chemical fertilizers. The content of $\mathrm{S}$ in tomato fruits varied from 0.05 to $0.39 \%$ (Table 3 ). Vermicompost at the rate of $10 \mathrm{t} \mathrm{ha}^{-1}$ and $50 \%$ chemical fertilizers treated plants $\left(\mathrm{T}_{7}\right.$ treatment) gave the highest $\mathrm{S}$ content $(0.39 \%)$ and minimum $\mathrm{S}$ content $(0.05 \%)$ was observed in $\mathrm{T}_{1}$ (control) treatment. The content of $\mathrm{S}$ in tomato fruits was improved in the combined used of organic manure with $\mathrm{N}, \mathrm{P}$ and $\mathrm{K}$ fertilizers (Hossain, 1996). The highest B content (31.00 $\mu \mathrm{g} \mathrm{g}^{-1}$ ) was observed in $\mathrm{T}_{7}$ (vermicompost @ 10 $\mathrm{t} \mathrm{ha}^{-1}$ and $50 \%$ chemical fertilizers) treatment and the lowest B content $\left(20.00 \mu \mathrm{g} \mathrm{g}^{-1}\right)$ was obtained in $\mathrm{T}_{1}$ (control) treatment. The content of $\mathrm{Zn}$ in fruit ranged from 21.00 to $32.00 \mu \mathrm{g} \mathrm{g}^{-1}$. The highest content of $\mathrm{Zn}$ $\left(32.00 \mu \mathrm{g} \mathrm{g}^{-1}\right)$ was obtained by application of vermicompost at the rate of $10 \mathrm{tha}^{-1}$ with $50 \%$ chemical fertilizers $\left(\mathrm{T}_{7}\right.$ treatment) and the lowest $\mathrm{Zn}$ content $\left(21.00 \mu \mathrm{g} \mathrm{g}^{-1}\right)$ was obtained from control $\left(\mathrm{T}_{1}\right)$ treatment (Table 3). Application of vermicompost gave the higher nutrient contents as compared to control treatment.

In Table 4, the content of $\mathrm{N}$ in tomato plant varied from 0.06 to $0.30 \%$. The highest $\mathrm{N}$ content $(0.30 \%)$ in tomato plant was obtained in $\mathrm{T}_{7}$ (vermicompost @ $10 \mathrm{t} \mathrm{ha}^{-1}$ and $50 \%$ chemical fertilizers) treatment and the lowest $\mathrm{N}$ content $(0.06 \%)$ was recorded in $\mathrm{T}_{1}$ (control) treatment, which was significantly inferior to all treatments.
Phosphorus content in tomato plant increased significantly due to the application of integrated use of vermicompost and chemical fertilizers. The content of $\mathrm{P}$ in tomato plant varied from 0.09 to $0.32 \%$. The highest $\mathrm{P}$ content $(0.32 \%)$ was observed in $\mathrm{T}_{7}$ (vermicompost @ $10 \mathrm{t} \mathrm{ha}^{-1}$ and $50 \%$ chemical fertilizers) treatment and the lowest $\mathrm{P}$ content $(0.09 \%)$ in tomato plant was found in $\mathrm{T}_{1}$ (control) treatment. The results clearly indicated that $\mathrm{P}$ content was increased in tomato plant due to the application of vermicompost and chemical fertilizers (Kadu et al., 1991). Potassium content in tomato plant ranged from 0.29 to $0.67 \%$. The highest $\mathrm{K}$ content $(0.67 \%)$ of tomato plant was obtained in $\mathrm{T}_{7}$ (vermicompost @ $10 \mathrm{t} \mathrm{ha}^{-1}$ and $50 \%$ chemical fertilizers) treatment and the lowest $\mathrm{K}$ content $(0.29 \%)$ was observed in $T_{1}$ (control) treatment. The result showed that the highest $\mathrm{K}$ content was increased with the application of vermicompost and chemical fertilizers. Singh (2001) revealed that K content in tomato plant increased due to the combination of vermicompost and chemical fertilizers. The content of $\mathrm{Ca}$ in plant varied from 0.51 to $1.40 \%$ (Table 4). Maximum $\mathrm{Ca}$ content $(1.40 \%)$ in tomato plant was observed in $\mathrm{T}_{7}$ (vermicompost @ $10 \mathrm{t} \mathrm{ha}^{-1}$ and $50 \%$ chemical fertilizers) treatment and that was minimum $(0.51 \%)$ in $\mathrm{T}_{1}$ (control) treatment. Vermicompost at the rate of $10 \mathrm{t} \mathrm{ha}^{-1}$ and $50 \%$ of chemical fertilizers $\left(\mathrm{T}_{7}\right.$ treatment) gave the highest $\mathrm{Mg}$ content (1.32\%) in tomato plant and the lowest $\mathrm{Mg}$ content $(0.75 \%)$ was found in control $\left(\mathrm{T}_{1}\right)$ treatment.

Table 4. Effect of vermicompost and chemical fertilizers on nutrient content of tomato plant

\begin{tabular}{|l|c|c|c|c|c|c|c|c|}
\hline \multicolumn{1}{|c|}{ Treatments } & $\begin{array}{c}\mathrm{N} \\
(\%)\end{array}$ & $\begin{array}{c}\mathrm{P} \\
(\%)\end{array}$ & $\begin{array}{c}\mathrm{K} \\
(\%)\end{array}$ & $\begin{array}{c}\mathrm{Ca} \\
(\%)\end{array}$ & $\begin{array}{c}\mathrm{Mg} \\
(\%)\end{array}$ & $\begin{array}{c}\mathrm{S} \\
(\%)\end{array}$ & $\begin{array}{c}\mathrm{B} \\
\left(\mu \mathrm{g}^{-1}\right)\end{array}$ & $\begin{array}{c}\mathrm{Zn} \\
\left(\mu \mathrm{g} \mathrm{g}^{-1}\right)\end{array}$ \\
\hline $\mathrm{T}_{1}-\mathrm{Control}$ & $0.06 \mathrm{e}$ & $0.09 \mathrm{e}$ & $0.29 \mathrm{e}$ & $0.51 \mathrm{e}$ & $0.75 \mathrm{e}$ & $0.12 \mathrm{e}$ & $2.20 \mathrm{e}$ & $1.12 \mathrm{e}$ \\
\hline $\mathrm{T}_{2}-\mathrm{CF}$ & $0.08 \mathrm{~d}$ & $0.10 \mathrm{~d}$ & $0.31 \mathrm{~d}$ & $0.69 \mathrm{~d}$ & $0.80 \mathrm{~d}$ & $0.21 \mathrm{~d}$ & $2.80 \mathrm{~d}$ & $1.28 \mathrm{~d}$ \\
\hline $\mathrm{T}_{3}-\mathrm{VC}_{1}$ & $0.12 \mathrm{c}$ & $0.17 \mathrm{c}$ & $0.39 \mathrm{c}$ & $0.85 \mathrm{c}$ & $0.87 \mathrm{c}$ & $0.32 \mathrm{c}$ & $3.00 \mathrm{c}$ & $1.52 \mathrm{c}$ \\
\hline $\mathrm{T}_{4}-\mathrm{VC}_{2}$ & $0.14 \mathrm{c}$ & $0.19 \mathrm{c}$ & $0.41 \mathrm{c}$ & $0.86 \mathrm{c}$ & $0.89 \mathrm{c}$ & $0.35 \mathrm{c}$ & $3.17 \mathrm{c}$ & $1.68 \mathrm{c}$ \\
\hline $\mathrm{T}_{5}-\mathrm{VC}_{1}+50 \% \mathrm{CF}$ & $0.25 \mathrm{~b}$ & $0.25 \mathrm{~b}$ & $0.49 \mathrm{~b}$ & $1.22 \mathrm{~b}$ & $1.25 \mathrm{~b}$ & $0.47 \mathrm{~b}$ & $3.87 \mathrm{~b}$ & $2.50 \mathrm{~b}$ \\
\hline $\mathrm{T}_{6}-\mathrm{VC}_{1}+75 \% \mathrm{CF}$ & $0.23 \mathrm{~b}$ & $0.26 \mathrm{~b}$ & $0.48 \mathrm{~b}$ & $1.12 \mathrm{~b}$ & $1.12 \mathrm{~b}$ & $0.45 \mathrm{~b}$ & $3.80 \mathrm{~b}$ & $2.45 \mathrm{~b}$ \\
\hline $\mathrm{T}_{7}-\mathrm{VC}_{2}+50 \% \mathrm{CF}$ & $0.30 \mathrm{a}$ & $0.32 \mathrm{a}$ & $0.67 \mathrm{a}$ & $1.40 \mathrm{a}$ & $1.32 \mathrm{a}$ & $0.52 \mathrm{a}$ & $4.50 \mathrm{a}$ & $2.56 \mathrm{a}$ \\
\hline $\mathrm{T}_{8}-\mathrm{VC}_{2}+75 \% \mathrm{CF}$ & $0.29 \mathrm{a}$ & $0.28 \mathrm{a}$ & $0.64 \mathrm{a}$ & $1.30 \mathrm{a}$ & $1.29 \mathrm{a}$ & $0.49 \mathrm{a}$ & $4.39 \mathrm{a}$ & $2.54 \mathrm{a}$ \\
\hline $\mathrm{LSD}_{0.05}$ & 0.053 & 0.054 & 0.092 & 0.075 & 0.075 & 0.10 & 0.18 & 0.13 \\
\hline Significance level $_{2}$ & $* *$ & $* *$ & $* *$ & $* *$ & $* *$ & $* *$ & $*$ & $* *$ \\
\hline $\mathrm{CV}(\%)$ & 17.95 & 16.32 & 13.78 & 5.69 & 4.62 & 17.83 & 3.10 & 5.25 \\
\hline
\end{tabular}

${ }^{* *}$ Significant at $1 \%$ level; $\mathrm{VC}_{1}=$ Vermicompost @ $5 \mathrm{t} \mathrm{ha}^{-1} ; \mathrm{VC}_{2}=$ Vermicompost @ $10 \mathrm{t} \mathrm{ha}^{-1}$ and $\mathrm{CF}=\mathrm{Recommended} \mathrm{dose}$ of chemical fertilizers. In a column, figures with same letter or without letter did not differ significantly whereas figures with dissimilar letter differed significantly as per DMRT.

The content of $\mathrm{S}$ in tomato plant varied from 0.12 to $0.52 \%$ (Table 4). The combined application of vermicompost at the rate of $10 \mathrm{t} \mathrm{ha}^{-1}$ and $50 \%$ chemical fertilizers $\left(\mathrm{T}_{7}\right.$ treatment) contributed the highest $\mathrm{S}$ content $(0.52 \%)$ in tomato plant and minimum $S$ content in tomato plant $(0.12 \%)$ was observed in $\mathrm{T}_{1}$ (control) treatment. Hossain (1996) obtained that $\mathrm{S}$ content in tomato plant was improved by the combined used of organic manure with N, P and K fertilizers. The highest $\mathrm{B}$ content $\left(4.50 \mu \mathrm{g} \mathrm{g}^{-1}\right)$ was observed in $\mathrm{T}_{7}$ (vermicompost @ $10 \mathrm{t} \mathrm{ha}^{-1}$ and $50 \%$ chemical fertilizers) treatment and the lowest content $(2.20 \mu \mathrm{g} \mathrm{g}$ ${ }^{1}$ ) was obtained in $T_{1}$ (control) treatment. The content of $\mathrm{Zn}$ in tomato plant ranged from 1.12 to $2.56 \mu \mathrm{g} \mathrm{g}^{-1}$. The highest $\mathrm{Zn}$ content $\left(2.56 \mu \mathrm{g} \mathrm{g}^{-1}\right)$ was observed from the application of vermicompost at the rate of $10 \mathrm{t} \mathrm{ha}^{-1}$ with $50 \%$ chemical fertilizers $\left(\mathrm{T}_{7}\right.$ treatment $)$ and the lowest 
Zn content $\left(1.12 \mu \mathrm{g} \mathrm{g}^{-1}\right)$ was obtained from control $\left(\mathrm{T}_{1}\right)$ treatment (Table 4).

\section{Effect of vermicompost and chemical fertilizers on nutrient status of postharvest soil}

The contents of $\mathrm{N}, \mathrm{P}, \mathrm{K}, \mathrm{Ca}, \mathrm{Mg}, \mathrm{B}$ and $\mathrm{Zn}$ in the postharvest soil increased significantly by the application of vermicompost and chemical fertilizers (Table 5). Maximum $\mathrm{pH}$ value (6.75) was found in vermicompost at the rate of $10 \mathrm{t} \mathrm{ha}^{-1}$ and $50 \%$ chemical fertilizers treated soil $\left(\mathrm{T}_{7}\right.$ treatment) and minimum $\mathrm{pH}$ value (6.32) was obtained in control $\left(\mathrm{T}_{1}\right)$ treatment. The integrated use of vermicompost and chemical fertilizers significantly influenced $\mathrm{pH}$ value of the postharvest soil. Maximum organic carbon (OC) content $(0.87 \%)$ was found from vermicompost at the rate of $10 \mathrm{t} \mathrm{ha}^{-1}$ and $50 \%$ chemical fertilizers treated soil $\left(\mathrm{T}_{7}\right.$ treatment) and minimum organic carbon (OC) content $(0.61 \%)$ was recorded in control $\left(\mathrm{T}_{1}\right)$ treatment. The combined application of organic manure and chemical fertilizers increased organic matter content in soil (Zhang et al., 1996). The highest $\mathrm{N}$ content $(0.90 \%)$ was found from vermicompost at the rate of $10 \mathrm{tha}^{-1}$ and $50 \%$ chemical fertilizers treated soil $\left(\mathrm{T}_{7}\right.$ treatment) and the lowest value $(0.06 \%)$ was recorded in control $\left(\mathrm{T}_{1}\right)$ treatment. Total $\mathrm{N}$ content gradually increased due to the effect of vermicompost and chemical fertilizers. Vermicompost and chemical fertilizers increased total $\mathrm{N}$ content in the postharvest soil (Reddy et al., 1998). Available P content varied from 17.12 to $32.50 \mu \mathrm{g} \mathrm{g}^{-1}$ (Table 5). The highest $\mathrm{P}$ content $\left(32.50 \mu \mathrm{g} \mathrm{g}^{-1}\right)$ was obtained from vermicompost at the rate of $10 \mathrm{t} \mathrm{ha}^{-1}$ and $50 \%$ chemical fertilizers treated soil $\left(\mathrm{T}_{7}\right.$ treatment) and the lowest $\mathrm{P}$ content (17.12 $\left.\mu \mathrm{g} \mathrm{g}^{-1}\right)$ was found in control $\left(\mathrm{T}_{1}\right)$ treatment. Interaction between organic and chemical fertilizers also showed an increasing effect of $\mathrm{P}$ content in soil. Application of organic fertilizer increased available $\mathrm{P}$ content in soil (Mathew and Nair, 1997; Wells et al., 2000; Abdel and Hussain, 2001; Iftikhar and Qasim, 2003). The highest content of exchangeable $\mathrm{K}\left(0.35 \mathrm{cmol} \mathrm{kg}{ }^{-1}\right)$ in the postharvest soil was obtained from vermicompost at the rate of $10 \mathrm{t} \mathrm{ha}^{-1}$ and $50 \%$ chemical fertilizers $\left(\mathrm{T}_{7}\right.$ treatment) and the lowest $\mathrm{K}$ content $\left(0.22 \mathrm{cmol} \mathrm{kg}^{-1}\right)$ was found in control $\left(\mathrm{T}_{1}\right)$ treatment. Significant effect of organic fertilizers improved exchangeable $\mathrm{K}$ content in soil as reported by Mathew and Nair (1997) and Wells et al. (2000). The highest exchangeable $\mathrm{Ca}$ content $\left(11.67 \mathrm{cmol} \mathrm{kg}^{-1}\right)$ was obtained in $\mathrm{T}_{7}$ treatment when vermicompost at the rate of $10 \mathrm{t} \mathrm{ha}^{-1}$ and $50 \%$ chemical fertilizers were applied and control $\left(\mathrm{T}_{1}\right)$ treatment gave the lowest value $(8.87$ $\left.\mathrm{cmol} \mathrm{kg}{ }^{-1}\right)$ in soils. The content of $\mathrm{Mg}$ in soil varied from 2.52 to $4.80 \mathrm{cmol} \mathrm{kg}^{-1}$. The highest $\mathrm{Mg}$ content $\left(4.80 \mathrm{cmol} \mathrm{kg}^{-1}\right)$ was obtained from vermicompost at the rate of $10 \mathrm{tha}^{-1}$ and $50 \%$ chemical fertilizers treated soil $\left(\mathrm{T}_{7}\right.$ treatment $)$ and the lowest $\mathrm{Mg}$ content $(2.52 \mathrm{cmol} \mathrm{kg}$ $\left.{ }^{1}\right)$ was obtained from control $\left(\mathrm{T}_{1}\right)$ treatment. The available $S$ content in the postharvest soil ranged from 10.87 to $21.47 \mu_{g^{-1}}$ (Table 5). The highest and lowest available $\mathrm{S}$ contents were obtained in $\mathrm{T}_{7}$ (vermicompost (a) $10 \mathrm{t} \mathrm{ha}^{-1}$ and $50 \%$ chemical fertilizers) and $\mathrm{T}_{1}$ (control) treatments, respectively. The combined use of organic fertilizer with NPK and S fertilizers improved the level of available $S$ in soil (Hossain, 1996; Azim, 1999). In the postharvest soil, the content of $B$ varied from 0.17 to $0.82 \mu \mathrm{g} \mathrm{g}^{-1}$. The highest B content $(0.82 \mu \mathrm{g}$ $\left.\mathrm{g}^{-1}\right)$ was obtained from vermicompost at the rate of $10 \mathrm{t}$ $\mathrm{ha}^{-1}$ and $50 \%$ chemical fertilizers treated soil $\left(\mathrm{T}_{7}\right.$ treatment) and the lowest B content $\left(0.17 \mu \mathrm{g} \mathrm{g}^{-1}\right)$ was recorded from control $\left(\mathrm{T}_{1}\right)$ treatment. The content of $\mathrm{Zn}$ in the postharvest soil was from 0.85 to $3.45 \mu \mathrm{g} \mathrm{g}^{-1}$ (Table 5).

Table 5. Effect of vermicompost and chemical fertilizers on nutrient status of the postharvest soil

\begin{tabular}{|l|c|c|c|c|c|c|c|c|c|c|}
\hline \multicolumn{1}{|c|}{ Treatments } & $\mathrm{pH}$ & $\begin{array}{c}\mathrm{OC} \\
(\%)\end{array}$ & $\begin{array}{c}\mathrm{Total} \mathrm{N} \\
(\%)\end{array}$ & $\begin{array}{c}\mathrm{P} \\
\left(\mu \mathrm{g} \mathrm{g}^{-1}\right)\end{array}$ & $\begin{array}{c}\mathrm{K} \\
\left(\mathrm{cmol} \mathrm{kg}^{-1}\right)\end{array}$ & $\begin{array}{c}\mathrm{Ca} \\
\left(\mathrm{cmol} \mathrm{kg}^{-1}\right)\end{array}$ & $\begin{array}{c}\mathrm{Mg} \\
\left(\mathrm{cmol} \mathrm{kg}^{-1}\right)\end{array}$ & $\begin{array}{c}\mathrm{S} \\
\left(\mu \mathrm{g} \mathrm{g}^{-1}\right)\end{array}$ & $\begin{array}{c}\mathrm{B} \\
\left(\mu \mathrm{g} \mathrm{g}^{-1}\right)\end{array}$ & $\begin{array}{c}\mathrm{Zn} \\
\left(\mu \mathrm{g} \mathrm{g}^{-1}\right)\end{array}$ \\
\hline $\mathrm{T}_{1}-\mathrm{Control}$ & $6.32 \mathrm{e}$ & $0.61 \mathrm{e}$ & $0.06 \mathrm{e}$ & $17.12 \mathrm{e}$ & $0.22 \mathrm{e}$ & $8.87 \mathrm{e}$ & $2.52 \mathrm{e}$ & $10.87 \mathrm{e}$ & $0.17 \mathrm{e}$ & $0.85 \mathrm{e}$ \\
\hline $\mathrm{T}_{2}-\mathrm{CF}$ & $6.58 \mathrm{~d}$ & $0.63 \mathrm{~d}$ & $0.21 \mathrm{~d}$ & $19.22 \mathrm{~d}$ & $0.25 \mathrm{~d}$ & $8.94 \mathrm{~d}$ & $2.70 \mathrm{~d}$ & $12.12 \mathrm{~d}$ & $0.34 \mathrm{~d}$ & $0.90 \mathrm{~d}$ \\
\hline $\mathrm{T}_{3}-\mathrm{VC}_{1}$ & $6.56 \mathrm{c}$ & $0.78 \mathrm{c}$ & $0.28 \mathrm{c}$ & $20.55 \mathrm{c}$ & $0.24 \mathrm{c}$ & $9.56 \mathrm{c}$ & $3.60 \mathrm{c}$ & $16.08 \mathrm{c}$ & $0.65 \mathrm{c}$ & $1.80 \mathrm{c}$ \\
\hline $\mathrm{T}_{4}-\mathrm{VC}_{2}$ & $6.55 \mathrm{c}$ & $0.81 \mathrm{~b}$ & $0.32 \mathrm{c}$ & $20.67 \mathrm{c}$ & $0.25 \mathrm{c}$ & $9.65 \mathrm{c}$ & $3.62 \mathrm{c}$ & $16.22 \mathrm{c}$ & $0.67 \mathrm{c}$ & $2.00 \mathrm{c}$ \\
\hline $\mathrm{T}_{5}-\mathrm{VC}_{1}+50 \% \mathrm{CF}$ & $6.64 \mathrm{c}$ & $0.85 \mathrm{a}$ & $0.37 \mathrm{~b}$ & $27.78 \mathrm{~b}$ & $0.32 \mathrm{~b}$ & $10.78 \mathrm{~b}$ & $3.87 \mathrm{~b}$ & $20.23 \mathrm{~b}$ & $0.78 \mathrm{~b}$ & $3.37 \mathrm{~b}$ \\
\hline $\mathrm{T}_{6}-\mathrm{VC}_{1}+75 \% \mathrm{CF}$ & $6.69 \mathrm{~b}$ & $0.82 \mathrm{~b}$ & $0.45 \mathrm{~b}$ & $29.33 \mathrm{~b}$ & $0.31 \mathrm{~b}$ & $10.58 \mathrm{~b}$ & $3.85 \mathrm{~b}$ & $20.16 \mathrm{~b}$ & $0.76 \mathrm{~b}$ & $3.34 \mathrm{~b}$ \\
\hline $\mathrm{T}_{7}-\mathrm{VC}_{2}+50 \% \mathrm{CF}$ & $6.75 \mathrm{a}$ & $0.87 \mathrm{a}$ & $0.90 \mathrm{a}$ & $32.50 \mathrm{a}$ & $0.35 \mathrm{a}$ & $11.67 \mathrm{a}$ & $4.80 \mathrm{a}$ & $21.47 \mathrm{a}$ & $0.82 \mathrm{a}$ & $3.45 \mathrm{a}$ \\
\hline $\mathrm{T}_{8}-\mathrm{VC}_{2}+75 \% \mathrm{CF}$ & $6.68 \mathrm{~b}$ & $0.84 \mathrm{a}$ & $0.89 \mathrm{a}$ & $32.13 \mathrm{a}$ & $0.33 \mathrm{a}$ & $10.87 \mathrm{a}$ & $4.78 \mathrm{a}$ & $21.26 \mathrm{a}$ & $0.81 \mathrm{a}$ & $3.41 \mathrm{a}$ \\
\hline $\mathrm{LSD}_{0.05}$ & 0.29 & 0.054 & 0.053 & 0.52 & 0.094 & 0.45 & 0.24 & 0.092 & 0.093 & 0.13 \\
\hline Significance level & $* *$ & $* *$ & $* *$ & $* *$ & $* *$ & $* *$ & $* *$ & $* *$ & $* *$ & $* *$ \\
\hline $\mathrm{CV}(\%)$ & 0.97 & 4.66 & 7.65 & 6.21 & 2.85 & 2.66 & 5.71 & 3.06 & 8.98 & 5.64 \\
\hline
\end{tabular}

${ }^{* *}$ Significant at $1 \%$ level; $\mathrm{VC}_{1}=$ Vermicompost @ $5 \mathrm{t} \mathrm{ha}^{-1} ; \mathrm{VC}_{2}=$ Vermicompost @ $10 \mathrm{t} \mathrm{ha}^{-1}$ and $\mathrm{CF}=\mathrm{Recommended}$ dose of chemical fertilizers. In a column, figures with same letter or without letter did not differ significantly whereas figures with dissimilar letter differed significantly as per DMRT.

The combined effect of vermicompost and chemical fertilizers on $\mathrm{Zn}$ content of the post harvest soil was significant. Maximum value $\left(3.45 \mu \mathrm{g} \mathrm{g}^{-1}\right)$ was obtained in $\mathrm{T}_{7}$ (vermicompost @ $10 \mathrm{t} \mathrm{ha}^{-1}$ and $50 \%$ chemical fertilizers) treatment and $\mathrm{T}_{1}$ (control) treatment recorded minimum value $\left(0.85 \mu \mathrm{g} \mathrm{g}^{-1}\right)$. Application of 
vermicompost had a significant influence on the improvement of soil micronutrient including Zn (Ansari and Sukhraj, 2010). Azarmi et al. (2008) reported that the addition of vermicompost in soil significantly increased organic $\mathrm{C}, \mathrm{N}, \mathrm{P}, \mathrm{K}$ and $\mathrm{Zn}$ contents substantially compared with control treatment for tomato cultivation. In this study, $\mathrm{T}_{7}$ (vermicompost @ $10 \mathrm{t} \mathrm{ha}^{-1}$ and 50\% chemical fertilizers) treatment showed the best performance, which was identical to $\mathrm{T}_{8}$ (vermicompost @ $10 \mathrm{t} \mathrm{ha}{ }^{-1}$ and $75 \%$ chemical fertilizers) treatment as compared to control $\left(\mathrm{T}_{1}\right)$ treatment. This finding might be due to the remarkable contribution of vermicompost enriched with nutrients as organic fertilizer.

\section{References}

Abdel, N.G. and Hussain, A.H.A. 2001. Effect of different manure sources on some soil properties and sunflower plant growth. Alexandria Journal of Agricultural Research, 46(1): 227-251.

Abduli, M.A.; Amiri, L.; Madadian, E.; Gitipour, S. and Sedighian, S. 2013. Efficiency of vermicompost on quantitative and qualitative growth of tomato plants. International Journal of Environmental Research, 7(2): 467-472.

Arancon, N.Q.; Edwards, C.A.; Bierman, P.; Metzger, J.D.; Lee, S. and Welch, C. 2003. Effects of vermicomposts on growth and marketable fruits of field-grown tomatoes, peppers and strawberries. Pedobiologia, 47: 731-735.

Ansari, A.A. and Sukhraj, K. 2010. Effect of vermiwash amd vermicompost on soil parameters and productivity of okra (Abelmoschus esculentum) in Guyana. Middle-East Journal of Scientific Research, 6(15): 429-435.

Azarmi, R.; Giglou, M.T. and Taleshmikail, R.D. 2008. Influence of vermicompost on soil chemical and physical properties in tomato (Lycopersicon esculentum L.) field. African Journal of Biotechnology, 7(14): 2397-2401.

Azim, S.M.A. 1999. Effect of sulphur, zinc and boron supplied from manures and fertilizers on BRRI Dhan-29. MS Thesis, Dept. of Soil Science, Bangladesh Agricultural University, Mymensingh.

Bhat, M.R. and Limaye, S.R. 2012. Nutrient status and plant growth promoting potential of prepared vermicompost. International Journal of Environmental Sciences, 3(1): 312-321.

Black, C.A. 1965. Methods of Soil Analysis. Part-II. Amer. Soc. Agron. Inc. Madison, Washington, USA. pp. 999-1492.

Ceglarek, R.J.; Rosa, R. and Framczuk, Y. 2002. Successive effect of green manures in the form of gone crops in cultivation of onion. Journal of Plant Nutrition and Soil Science, 14(1): 3-12.

Chadha, S.; Rana, S.S. and Chaudhury, D.R. 2006. Nutrient management in summer onion (Allium сера) under cold desert conditions of North Western Himalayas. Indian Journal of Agricultural Science, 76(10): 629-631.

\section{Conclusions}

From the study, it is concluded that vermicompost as organic fertilizer can reduce the application of chemical fertilizer for tomato cultivation and thus may minimize the cost of cultivation. Application of vermicompost at the rate of $10 \mathrm{t} \mathrm{ha}^{-1}$ along with $50 \%$ chemical fertilizers showed the best performance in terms of yield and quality of tomato as well as soil fertility management. The combined application of vermicompost and chemical fertilizers would help to maintain the longterm soil productivity for sustainable tomato cultivation.

Chanda, G.K.; Bhunia, G. and Chakraborty, S.K. 2011. The effect of vermicompost and other fertilizers on cultivation of tomato plants. Journal of Horticulture and Forestry, 3(2): 42-45.

Ghosh, A.B.; Bajaj, J.C.; Hasan, R. and Singh, D. 1983. Soil and Water Testing Method - A Laboratory Manual. Division of Soil Science and Agricultural Chemistry, IARI, New Delhi, India. pp. 221-226.

Gomez, K.A. and Gomez, A.A. 1984. Statistical Procedures for Agricultural Research. 2nd ed., John Willy and Sons, New York. pp. 18-192.

Hossain, M.B. 1996. Integrated nutrient management for BR-11 rice. MS Thesis, Dept. of Soil Science, Bangladesh Agricultural University, Mymensingh.

Iftikhar, A. and Qasim, M. 2003. Influence of various potting media on growth and nutrient uptake efficiency of Scindapsus aureus. International Journal of Agriculture \& Biology, 5(4): 594-597.

Jackson, M.L. 1973. Soil Chemical Analysis. Prentice Hall of India Pvt. Ltd., New Delhi, India. pp. 151154.

Jin, H.J.; Kim, J.G.; Cho, Y.M.; Kway, J.H.; Shin, J.S. and Lee, H.H. 1996. Growth, yields and quality of rice cultivated on paddy soils as after crop fodder the under heavy application of animal manures. Journal of the Korean Society of Grassland and Forage Science, 16(4): 338-342.

Kadu, P.B.; Bhoyar, V.S. and Thakare, R.S. 1991. Effect of NPK-FYM balanced manorial mixtures on performance of soybean. Journal of Soils and Crops, 1(2): 172-174.

Maheswarappa, H.P.; Nanjappa, H.V. and Hegde, M.R. 1999. Influence of organic manures on yield of arrow root, soil physico-chemical and biological properties when grown as intercrop in coconut garden. Annals of Agricultural Research, 20(3): 318323.

Marinari, S.; Masciandaro, G.; Ceccanti, B. and Grego, S. 2000. Influence of organic and mineral fertilizers on soil biological and physical properties. Bioresource Technology, 72(1): 9-17.

McLaren, R.G.; Swift, R.S. and Qwin, B.F. 1984. EDTA extractable copper, zinc, iron and manganese in soils of the Conterbury plains. New Zealand Journal of Agricultural Research, 27: 207-217. 
Mathew, T. and Nair, S.S. 1997. Physical and chemical properties of rice soils as influenced by organic and inorganic sources of nutrients. Indian Journal of Agricultural Research, 31(4): 257-261.

Naresh, B. 2002. Response of foliar application of boron on vegetative growth, fruit yield quality of tomato var. Pusa-Ruby. Indian Journal of Hill Farming, 15(1): 109-112.

Page, A.L.; Miller, R.H. and Keeney, D.R. (Editors). 1982. Methods of Soil Analysis, Part-2. Chemical and Microbiological Properties. 2nd ed., Amer. Soc. Agron. Inc. Madison, Washington, USA. pp. 98765.

Ranganna, S. 1994. Handbook of Analysis of Quality Control for Fruit and Vegetables Products. Tata McGraw-Hill Publishing Co. Ltd., New Delhi, India.

Reddy, B.N., Sinha, M.N. and Rai, R.K. 1998. Effect of irrigation, nitrogen and phosphorus on $\mathrm{N}$ and $\mathrm{P}$ uptake by mustard (Brassica juncea) at various stages of growth. Annals of Agricultural Research, 9(1): 129-133.

Singh, B.P. 2001. Effect of farmyard manure and inorganic fertilizer on growth and yield of soybean. Agricultural Science Digest, 21(1): 21-24.
Singh, D.; Chhonkar, P.K. and Pandey, R.N. 1999. Soil Plant Water Analysis: A Method Manual. IARI, New Delhi, India. pp. 80-82.

Tandon, H.L.S. 1995. Methods of Analysis of Soils, Plants, Water and Fertilizers. Fertilizer Development and Consultation Organization New Delhi, India. pp. 44-45.

Theunissen, J.; Ndakidemi, P.A. and Laubscher, C.P. 2010. Potential of vermicompost produced from plant waste on the growth and nutrient status in vegetable production. International Journal of the Physical Sciences, 5(13): 1964-1973.

Wells, A.T.; Chan, K.Y. and Cornish, P.S. 2000 Comparison of conventional and alternative vegetable farming system on the properties of a yellow earth in New South Wales. Agriculture, Ecosystems \& Environment, 80(1-2): 47-60.

Yadav, P.V.S.; Abha, T. and Sharma, N.K. 2001. Effect of zinc and boron on growth, flowering and fruiting of tomato (Lycopersicon esculentum, Mill). Haryana Journal of Horticultural Science, 30(1/2): 105-107.

Zhang, M.; Gu, H. and Peng, P. 1996. Study on combined application of organic and inorganic fertilizers in dry and poor red paddy soils. Rice Abstract, 20(1): 32. 